VIEWPOINT

\title{
A need for greater reporting of socioeconomic status and race in clinical trials
}

\author{
S J Lee, A Kavanaugh
}

Ann Rheum Dis 2004;63:1700-1701. doi: 10.1136/ard.2003.019588

C omprehensive data about new treatments for rheumatoid arthritis (RA), including their potential for disease remission, efficacy, and safety, are derived from clinical research. Often these studies can significantly influence management strategies for patients with RA. Virtually all recent studies on RA report disease characteristics relevant to outcome. Factors such as the presence of rheumatoid factor, the number of tender and swollen joints, measurements of acute phase reactants, the presence of radiographic erosions, and prior treatments with disease modifying antirheumatic drugs define the severity of disease, and also, the potential for responses to treatments. The age and sex of the study population are also reported in every study, although their effect on disease outcome is less clear.

However, many clinical studies, including some landmark studies that have dramatically shaped our approach to RA, fail to report other key demographic information. For example, race and socioeconomic status (SES), two potentially critical factors affecting the outcome of patients with $\mathrm{RA}$, are seldom reported in publications (table 1$) \cdot{ }^{1-17} \mathrm{~A}$ number of studies have demonstrated that disease outcome in RA correlates inversely and strongly with SES and education. ${ }^{18-20}$ Although the data on RA are limited, studies in systemic lupus erythematosus and in non-rheumatological conditions have shown that race can be associated with worse disease prognosis, a more aggressive disease, and a greater functional decline. ${ }^{21-25}$ Furthermore, race can influence the efficacy profile of various therapeutic agents. ${ }^{26-29}$ Some of the hypotheses to explain these racial differences in the prevalence of disease and the response to treatment have included genetic polymorphisms, differences in SES, and disparities in healthcare use. A better understanding of the role of race on treatment modalities will require inclusion and reporting of race in clinical studies along with subgroup analysis by race.

A heterogeneous study group that reflects the general population with RA is also important for the generalisability of clinical studies. A survey of some recently published clinical trials illustrates that, in general, minorities may be underrepresented in RA therapeutic trials (table 1). Interestingly, it has been suggested that minority patients may be less willing to participate in clinical studies owing to factors such as distrust of physicians/clinical studies, insufficient knowledge about continuing trials, and lower expectations from clinical trials. ${ }^{30-34}$

In many cases, the racial composition, SES, and education may be collected but not be presented in many pivotal trials in rheumatology. Self report of race, SES, and education is inexact but can be easily performed and has been used routinely in many studies. Despite the inexactness inherent in the process, significant correlations have been noted between self reported race, ethnicity, and disease outcome. ${ }^{35}$

\begin{tabular}{|c|c|c|c|c|}
\hline Agent [reference] & Study group & Racial composition & SES* & Education \\
\hline Rituximab' & 22 & Not reported & Not reported & Not reported \\
\hline CTLA- $4 \mathrm{lg}^{2}$ & 214 & $\begin{array}{l}\text { White } 194(91 \%) \\
\text { Black } 9(4 \%) \\
\text { Other } 11(5 \%)\end{array}$ & Not reported & Not reported \\
\hline Etanercept $^{3}$ & 628 & $\begin{array}{l}\text { White } 576(92 \%) \\
\text { Black } 18(3 \%) \\
\text { Hispanic } 15(2 \%) \\
\text { Asian } 12(2 \%) \\
\text { Other } 7(1 \%)\end{array}$ & Not reported & Not reported \\
\hline $\mathrm{SSZ}+\mathrm{HCQ}+\mathrm{MTX}^{4}$ & 102 & Not reported & Not reported & Not reported \\
\hline Leflunomide+MTX & 263 & $\begin{array}{l}\text { White } 234(89 \%) \\
\text { Black } 15(6 \%) \\
\text { Asian } 8(3 \%) \\
\text { Other } 6(2 \%)\end{array}$ & Not reported & Not reported \\
\hline $\mathrm{CSA}+\mathrm{MTX}^{6}$ & 148 & $\begin{array}{l}\text { White } 137(93 \%) \\
\text { Asian } 11(7 \%)\end{array}$ & Not reported & Not reported \\
\hline SSZ+MTX+prednisone ${ }^{7}$ & 155 & Not reported & Not reported & Not reported \\
\hline$S S Z+H C Q+M T X^{8}$ & 195 & Not reported & Not reported & Not reported \\
\hline Prednisone ${ }^{9}$ & 128 & Not reported & Not reported & Not reported \\
\hline MTX $^{10}$ & 123 & Not reported & Not reported & Not reported \\
\hline Leflunomide" & 482 & Not reported & Not reported & Not reported \\
\hline Leflunomide $^{12}$ & 358 & Not reported & Not reported & Not reported \\
\hline MTX+leflunomide ${ }^{13}$ & 999 & Not reported & Not reported & Not reported \\
\hline Infliximab ${ }^{14}$ & 428 & White 389 (91\%) & Not reported & Not reported \\
\hline Etanercept+MTX ${ }^{15}$ & 89 & White $70(79 \%)$ & Not reported & Not reported \\
\hline Etanercept $^{16}$ & 633 & White 544 (86\%) & Not reported & Not reported \\
\hline Adalimumab $^{17}$ & 271 & Not reported & Not reported & Not reported \\
\hline
\end{tabular}


Greater availability of this information, either in the publication or on line, will improve our understanding of the safety and efficacy of various therapeutic agents. Also, inclusion of racially and economically heterogeneous populations of patients with RA will increase the external validity of the trial results.

\section{Authors' affiliations}

S J Lee, A Kavanaugh, University of California, San Diego, Division of Rheumatology, Allergy, and Immunology, La Jolla, CA, USA

Correspondence to: Dr A Kavanaugh, 9320 Campus Point Dr, Suite 225, La Jolla, CA 92037-0943, USA; akavanaugh@ucsd.edu

Accepted 16 February 2004

\section{REFERENCES}

1 Leandro MJ, Edwards JCW, Cambridge G. Clinical outcome in 22 patients with rheumatoid arthritis treated with B lymphocyte depletion. Ann Rheum Dis 2002;61:883-8.

2 Moreland LW, Alten R, Van den Bosch F, Appelboom T, Leon M, Emery P, et al. Costimulatory blockade in patients with rheumatoid arthritis. Arthritis Rheum 2002;46:1470-9.

3 Moreland LW, Cohen SB, Baumgartner SW, Tindall EA, Bulpitt K, Martin R, et al. Longterm safety and efficacy of etanercept in patients with rheumatoid arthritis. J Rheumatol $2001 ; 28: 1238-44$

4 O'Dell JR, Haire CE, Erikson N, Drymalski W, Palmer W, Eckhoff PJ, et al. Treatment of rheumatoid arthritis with methotrexate alone, sulfasalazine and hydroxychloroquine, or a combination of all three medications. N Engl J Med 1996:334:1287-91.

5 Kremer JM, Genovese MC, Cannon GW, Caldwell JR, Cush JJ, Furst DE, et al. Concomitant leflunomide therapy in patients with active rheumatoid arthritis despite stable doses of methotrexate. Ann Intern Med 2002;137:726-33.

6 Tugwell P, Pincus T, Yocum D, Stein M, Gluck O, Kraag G, et al. Combination therapy with cyclosporine and methotrexate in severe rheumatoid arthritis. N Engl J Med 1995;333:137-41.

7 Boers M, Verhoeven AC, Markusse HM, van de Laar MA, Westhovens R, van Denderen JC et al. Randomised comparison of combined step-down prednisolone, methotrexate and sulphasalazine with sulphasalazine alone in early rheumatoid arthritis. Lancet 1997;350:309-18.

8 Mottonen $\mathrm{T}$, Honnonen $\mathrm{P}$, Leirisalo-Repo $M$, Nissila $M$, Kautiainen $\mathrm{H}$ Korpela $M$, et al. Comparison of combination therapy with single-drug therapy in early rheumatoid arthritis: a randomised trial. Lancet 1999;353:1568-73.

9 Kirwan J. Arthritis and Rheumatism Council Low-Dose Glucocorticoid Study Group. The effect of glucocorticoids on joint destruction in rheumatoid arthritis. N Engl J Med 1995;333:142-6.

10 Weinblatt ME, Kaplan H, Germain BF, Block S, Solomon SD, Merriman RC, et al. Methotrexate in rheumatoid arthritis. Arthritis Rheum 1994:37:1492-8.

11 Strand V, Cohen S, Schiff M, Weaver A, Fleischmann R, Cannon G, et al. Treatment of active rheumatoid arthritis with leflunomide compared with placebo and methotrexate. Arch Intern Med 1999;159:2542-50.

12 Smolen JS, Kalden JR, Scott DL, Rozman B, Kvien TK, Larsen A, et al. Efficacy and safety of leflunomide compared with placebo and sulphasalazine in active rheumatoid arthritis: a double-blind, randomised, multicentre trial. Lancet 1999;353:259-66.

13 Emery P, Breedveld FC, Lemmel EM, Kaltwasser JP, Dawes PT, Gomor B, et al. $A$ comparison of the efficacy and safety of leflunomide and methotrexate for the treatment of rheumatoid arthritis. Rheumatology (Oxford) 2000;39:655-65

14 Maini R, St Clair EW, Breedveld F, Furst D, Kalden J, Weisman M, et al. Infliximab (chimeric anti-tumour necrosis factor $\alpha$ monoclonal antibody) versus placebo in rheumatoid arthritis patients receiving concomitant methotrexate: a randomised phase III trial. Lancet 1999;354:1932-9.

15 Weinblatt ME, Kremer JM, Bankhurst AD, Bulpitt KJ, Fleischmann RM, Fox RI, et al. A trial of etanercept, a recombinant tumor necrosis factor receptor:Fc fusion protein, in patients with rheumatoid arthritis receiving methotrexate. N Engl J Med 1999;340:253-9.

16 Bathon JM, Martin RW, Fleischmann RM, Tesser JR, Schiff MH, Keystone EC, et al. A comparison of etanercept and methotrexate in patients with early rheumatoid arthritis. N Engl J Med 2000;343:1586-93.

17 Weinblatt ME, Keystone EC, Furst DE, Moreland LW, Weisman MH, Birbara CA, et al. Adalimumab, a fully human anti-tumor necrosis factor $\alpha$ monoclonal antibody, for the treatment of rheumatoid arthritis in patients taking concomitant methotrexate: ARMADA trial. Arthritis Rheum 2003;48:35-45.

18 Pincus T, Callahan LF. Formal education as a marker for increased mortality and morbidity in rheumatoid arthritis. J Chron Dis 1985;38:973-84.

19 Callahan LF, Pincus T. Formal education level as a significant marker of clinical status in rheumatoid arthritis. Arthritis Rheum 1988;31:1346-57.

20 Criswell LA, Katz PP. Relationship of education level to treatment received for rheumatoid arthritis. J Rheumatol 1994;21:2026-33.

21 Jordan JM. Effect of race and ethnicity on outcomes in arthritis and rheumatic conditions. Curr Opin Rheumatol 1999;11:98-103.

22 Halevy D, Radhakrishnan J, Appel GB. Racial and socioeconomic factors in glomerular disease. Semin Nephrol 2001;21:403-10.

23 Vaccarino V, Gahbaver E, Kasl SV, Charpentier PA, Acampora D Krumholz HM. Differences between African Americans and whites in the outcome of heart failure: evidence for a greater functional decline in African Americans. Am Heart J 2002;143:1058-67.

24 Al-Othman MO, Morris CG, Logan HL, Hinerman RW, Amdur RJ, Mendenhall WM. Impact of race on outcome after definitive radiotherapy for squamous cell carcinoma of the head and neck. Cancer 2003;98:2467-72.

25 Govindarajan R, Shah RV, Erkman LG, Hutchins LF. Racial differences in the outcome of patients with colorectal carcinoma. Cancer 2003;97:493-8.

26 Flack JM, Oparil S, Pratt JH, Roniker B, Garthwaite S, Kleiman JH, et al. Efficacy and tolerability of eplerenone and losartan in hypertensive black and white patients. J Am Coll Cardiol 2003;41:1148-55.

27 Preston RA, Materson BJ, Reda DJ, Williams DW, Hamburger RJ, Cushman WC, et al. Age-race subgroup compared with rennin profile as predictors of blood pressure response to antihypertensive therapy. JAMA 1998;280:1168-72

28 Venter $\mathrm{CP}$, Joubert PH. Ethnic differences in response to $\beta$-adrenoceptor blockade by propanolol. J Cardiovasc Pharmacol 1984:6:361-4.

29 Materson BJ, Reda DJ, Cushman WC, Massie BM, Freis ED, Kochar MS, et al. Single-drug therapy for hypertension in men-a comparison of six antihypertensive agents with placebo. N Engl J Med 1993;328:914-21.

30 Shavers VL, Lynch CF, Burmeister LF. Racial differences in factors that influence the willingness to participate in medical research studies. Ann Epidemiol 2002;12:248-56

31 Robertson, NL. Clinical trial participation. Cancer 1994;74:2687-91.

32 Shavers VL, Lynch CF, Burmeister LF. Factors that influence AfricanAmericans' willingness to participate in medical research studies. Cancer $2001 ; 91$ (suppl 1):233-6.

33 Fouad MN, Partridge E, Wynn T, Green BL, Kohler C, Nagy S. Statewide Tuskegee Alliance for clinical trials. A community coalition to enhance minority participation in medical research. Cancer 2001;91(suppl 1):237-41.

34 Corbie-Smith G, Thomas S, St George D. Distrust, race, and research. Intern Med 2002;162:2458-63.

35 Gifford AL, Cunningham, WE, Heslin KC, Andersen RM, Nakazono T, Lieu DK, et al. Participation in research and access to experiemntal treatments by HIV-infected patients. N Engl J Med 2002;346:1373-82. 